\title{
Neurological and psychiatric manifestations in idiopathic hypoparathyroidism: response to treatment
}

\author{
M. HOSSAIN ${ }^{1}$ \\ From the Department of Clinical Investigation, The General Infirmary, Leeds
}

Patients with hypoparathyroidism may develop psychiatric symptoms. Others, like the two patients we present here may have symptoms which are more typical of organic brain disease. A feature common to the two patients is that the symptoms were only controlled when the hypocalcaemia was abolished; less specific forms of treatment failed.

\section{CASE 1}

Miss V.C., aged 54, had attacks of tetany for 34 years but was otherwise well. From about May 1965 she became increasingly confused and her personality deteriorated. A psychiatrist who examined her in April 1966 diagnosed presenile dementia and gave her chlorpromazine $25 \mathrm{mg}$ q.d.s. Within a few weeks she was jaundiced and was admitted to another hospital. The jaundice disappeared on withdrawal of the drug, the serum bilirubin falling from $11 \mathrm{mg} / 100 \mathrm{ml}$. to $2 \mathrm{mg} / 100 \mathrm{ml}$., but she remained mentally confused and had continuous gross involuntary movements. None of the members of the patient's family were known to have had symptoms of mental confusion or involuntary movements. On examination her hair was dry and brittle and when the knee and ankle jerks were elicited there was plantar flexion of both feet with adduction of toes. Trousseau's test was positive. The serum calcium was $6.4 \mathrm{mg} / 100 \mathrm{ml}$. A radiograph of the skull showed extensive intracerebral calcification. She was thought to have idiopathic hypoparathyroidism, and in order to examine the relation between this and the confusional state she was transferred to Leeds General Infirmary.

Her mental condition was one of disorientation in time and space, with impairment of memory and concentration. She had flights of ideas with occasional perseveration and continuous choreiform movements of the face, head, and all four limbs. These movements had a hemiballismic character. Figure 1 shows a specimen of her handwriting. The reflexes were brisk and symmetrical, and the plantar responses were flexor. There were no opacities in the lenses. Trousseau's test was positive at one minute.

'Present address: M.R.C. Mineral Metabolism Unit, The General Infirmary, Leeds.
INVESTIGATIONS The serum calcium was $4.9 \mathrm{mg} / 100 \mathrm{ml}$., serum magnesium $1.45 \mathrm{mg} / 100 \mathrm{ml}$, and the serum inorganic phosphorus $6.6 \mathrm{mg} / 100 \mathrm{ml}$. The serum alkaline phosphatase was $14 \mathrm{KA} \mathrm{u} . / 100 \mathrm{ml}$., with a heat stability index of $0 \cdot 27$. The blood urea was $18 \mathrm{mg} / 100 \mathrm{ml}$. Electrocardiography showed rather flat $T$ waves, and long Q-T intervals; these findings are compatible with low serum calcium.

The plasma protein content was normal, as was the composition of the cerebrospinal fluid. The only radiological abnormality was extensive intracerebral calcification, distributed throughout the basal ganglia. The electroencephalograph was normal and was not altered by hyperventilation.

A sample of trabecular bone, by trephine from the iliac crest, was histologically normal.

TREATMENT AND PROGRESS Her involuntary movements stopped immediately after intravenous diazepam $(10 \mathrm{mg})$.

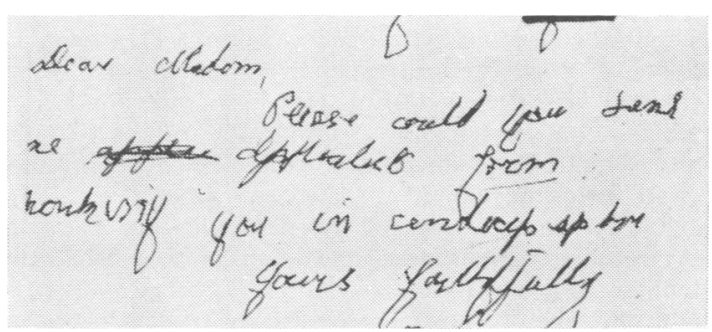

FIG. 1. Specimen of the patient's handwriting on admission (5 May 1966).

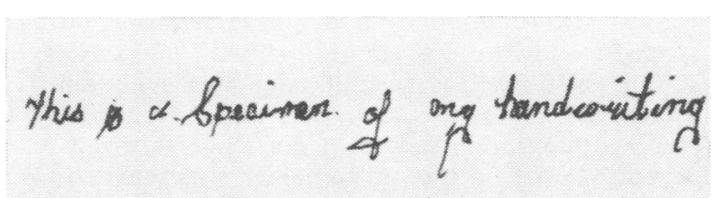

FIG. 2. Specimen of the patient's handwriting when her choreiform movement was controlled (10 June 1966). 
They recurred two hours later although not to the same extent as before. In view of this improvement she was given diazepam by mouth, at first $20 \mathrm{mg}$ and later $75 \mathrm{mg}$ per day. Although this treatment partly controlled the involuntary movements she remained agitated and depressed. She also had attacks of tetany with laryngeal stridor and on one occasion with a generalized convulsion. The tetany was abolished by an intravenous injection of calcium gluconate. She was then given calciferol $2 \mathrm{mg} /$ day $(80,000 \mathrm{u}$.) with $2.4 \mathrm{~g}$ effervescent calcium (Sandoz). Her serum calcium rose and at the same time her involuntary movements diminished. Figure 2 shows a specimen of her handwriting one month after beginning calciferol, when her serum calcium was $9.5 \mathrm{mg} / 100 \mathrm{ml}$. By this time she was less confused and she required only $2.5 \mathrm{mg}$ diazepam per day. Her memory had improved, she appeared more intelligent, and her involuntary movements had ceased. Her behaviour continued to improve while her serum calcium was maintained at 9.5 to $10.5 \mathrm{mg} / 100 \mathrm{ml}$. with $1 \mathrm{mg}$ vitamin $D_{2}$ daily. In March 1967, the diazepam was stopped without any immediate deterioration in her mental state.

By July 1967, she was hyperactive and much more talkative. Her serum calcium was then $8 \mathrm{mg} / 100 \mathrm{ml}$. A month later she was admitted to hospital, and on examination her serum calcium was found to have fallen to $7.2 \mathrm{mg} / 100 \mathrm{ml}$. She had motor restlessness with an associated tremor, a marked increase in tone, and some cog-wheel rigidity. Psychiatric opinion was that the patient was hypomanic, most probably related to some metabolic disturbance in a setting of long-standing organic deterioration. She was given benzhexol $2 \mathrm{mg}$ t.d.s. and haloperidol starting at $0.75 \mathrm{mg}$ t.d.s. and increasing to a maintenance dose of $1.5 \mathrm{mg}$ t.d.s.

The patient's serum calcium rose to $9 \mathrm{mg} \%$ during the next three months on calciferol (vitamin $\mathrm{D}_{2}$ ) $1 \mathrm{mg} /$ day. Her mental state improved gradually, she became less agitated, and her involuntary movements disappeared. Haloperidol was withdrawn without a recurrence of her symptoms. She was discharged on vitamin $D_{2} 1 \mathrm{mg}$ a day and $2.4 \mathrm{~g}$ effervescent calcium (Sandoz); her serum calcium was $10 \mathrm{mg} / 100 \mathrm{ml}$. Her last admission was in March 1969 when she was found to be restless, agitated, and unable to sit quietly; there were continuous choreiform movements of all four limbs. Her serum calcium was $8.3 \mathrm{mg} / 100 \mathrm{ml}$. Intravenous diazepam produced no apparent effect. In order to alleviate her mental condition while her vitamin $D$ therapy was being adjusted, she was given large doses of tranquillizers and unfortunately developed bilateral hypostatic pneumonia. Because of her weakened physical condition, vitamin D therapy was difficult to administer, and her serum calcium fell further, to $7.5 \mathrm{mg} \%$. After her chest infection improved with antibiotics and physiotherapy, she was started on dihydrotachysterol (DHT) $0.5 \mathrm{mg}$ per day, her serum calcium rose steadily and was maintained at $10 \mathrm{mg} / 100 \mathrm{ml}$. At the same time her choreiform movements disappeared and have not since recurred. Concurrently, her acute hypomania was treated with increasing doses of haloperidol. At the time of writing her serum calcium is $9.5 \mathrm{mg} / 100 \mathrm{ml}$. on DHT $0.5 \mathrm{mg} /$ day, and the dose of the haloperidol is being reduced. She is mentally and physically well and able to carry out her daily duties.

CASE 2

A.P., aged 16, had his first fit aftei a 'flu-like' illness whe? he was 14 years old. The fits, which occurred frequently during the next two years, took the form of loss of cone sciousness lasting about 30 seconds and clonic movement? of limbs lasting half to one hour. As the attacks recurre he became an anxious child and began to lag behind his. classmates so that in September 1966 he was transferred to a lower form at school. He was referred to a neurologist? in 1967 for investigation of his fits. Extensive neurologicat examination and investigation, including electroencepha을 lography, lumbar puncture, and air encephalography faileof to reveal any cause for the fits. He was given diazepang $10 \mathrm{mg}$ q.d.s. and phenytoin $50 \mathrm{mg}$ t.d.s. and sent homea However, he continued to have fits and was readmitted iff November 1967. When the serum calcium was measured for the first time it was found to be $5.8 \mathrm{mg} / 100 \mathrm{ml}$. He was transferred for further investigations with the follow $\vec{\omega}$ ing results. The serum calcium was $5.5 \mathrm{mg} / 100 \mathrm{ml}$, the serum inorganic phosphorus was $11.2 \mathrm{mg} / 100 \mathrm{ml} \cdot \frac{\overline{2}}{2}$ the serum magnesium was $1.94 \mathrm{mg} / 100 \mathrm{ml}$, , the serunp alkaline phosphatase $39 \mathrm{KA}$ units, and the blood urew $15 \mathrm{mg} / 100 \mathrm{ml}$. The urine calcium was $15 \mathrm{mg}$ in 24 hoursin The Ellsworth-Howard test showed a response of 7 renal tubules to an injection of parathyroid hormone

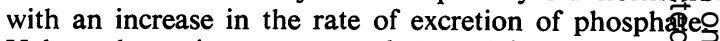
Xylose absorption was normal. Faecal fats were within the normal range. A radiological skeletal survey was normal, as was the bone biopsy.

It appeared that this boy had idiopathic hypoparaa thyroidism. As a first measure in the correction of $\mathbb{A}$ e hypocalcaemia we attempted to reduce the sermo phosphorus. He was given aluminium hydroxide, $15 \mathrm{ml}$ four times a day, in an attempt to diminish phosphate? absorption, but there was no change in the seruns calcium or phosphorus. A week later he was given, in addition, probenecid $2 \mathrm{~g}$ a day with the aim of increasing the excretion of phosphorus in the urine. There was little change in the patient's serum phosphorus, but the serum calcium increased. When dihydrotachysterol (DHT) was given in addition to aluminium hydroxide and the serum calcium rose to within normal values, the serum phos phorus fell and he had no more fits. Progressive with? drawal of aluminium hydroxide, probenecid, and the anti-epileptic therapy produced no recurrence of his symptoms or a change in the serum calcium or phos:phorus. He has made a complete recovery; he is more placid and a much less troublesome child. The standard of his work at school has improved immensely.

\section{DISCUSSION}

Gross mental retardation and symptoms of hypo 근. mania and hallucinations, as encountered in our firster case, have been observed in a few patients with idiopathic hypoparathyroidism (Simpson, 1952 N Rose and Vas, 1966). These were usually patients 
who had escaped diagnosis for many years. However, $80 \%$ of the cases studied by Denko and Kaelbling (1962) had intellectual impairment (IQ 40 to 90 ) as the sole or major psychiatric finding. Mental impairment is reversed in about $50 \%$ of the patients (Berezin and Stein, 1948; Treusch, 1957; Denko and Kaelbling, 1962) when the serum calcium is brought into the normal range, as was the case in both of our patients.

Calcification of the basal ganglia is a reflection of long-standing hypocalcaemia (Eaton and Haines, 1939; Danowski, Lasser, and Wechsler, 1960) and its presence should lead one to look for abnormalities of calcium metabolism. Naef and Adle (1959), in a discussion on calcification of the basal ganglia, state that the calcification is bilaterally symmetrical and is dense in the caudate nucleus and globus pallidus. There is hyalinization and deposition of calcium within the walls of the small blood vessels, chiefly in the media and adventitia. Profound involvement of the vessels is associated with degeneration and loss of ganglion cells. The crystalline form of the pathological deposits of calcium is that of the natural apatites-that is, $3 \mathrm{Ca}_{3}\left(\mathrm{PO}_{4}\right)_{2} \mathrm{Ca} \mathrm{x}_{2}$, where $\mathrm{x}$ may represent a variety of substances. The apatite of bone is probably a hydroxyapatite, $3 \mathrm{Ca}_{3}\left(\mathrm{PO}_{4}\right)_{2} \mathrm{CaOH}_{2}$, but its composition is modified by the ions substituted at the surface of the crystals in particular, carbonate may substitute for phosphates. Presence of calcification in the basal ganglia is not necessarily accompanied by central nervous system disorder (Naef and Adle, 1959; Muenter and Whisnant, 1968) and the condition is not unique to hypoparathyroidism. It has also been noted in encepha- litis lethargica, carbon monoxide poisoning, hypoxia, tuberous sclerosis, paralysis agitans, old intracerebral thrombosis, and spinal tumor (Bennett, Maffly, and Steinbach, 1959; McKinney, 1962; Muenter and Whisnant, 1968).

Chorea is a very rare manifestation in hypoparathyroidism associated with calcification of the basal ganglia, and only one case has been reported by Simpson (1952) in the British literature. McKinney (1962) reviewed the literature of cases with either idiopathic hypoparathyroidism or pseudohypoparathyroidism and found 17 cases of patients who demonstrated abnormal movement, but only four of these cases demonstrated choreiform movement. One of the cases had evidence of calcification of the basal ganglia. The four cases are summarized in Table 1. Muenter and Whisnant (1962), in a review of cases from Mayo Clinic between 1935 and 1966, found 38 patients with bilateral calcification of the basal ganglia of whom nine patients had hypoparathyroidism and evidence of neurological disorder. The neurological abnormalities were movement disorders, seizures, retinal degeneration, hemianopia, cranial nerve deficit, cerebellar dysfunction, and dementia. They noticed that in the majority of cases of calcification of the basal ganglia associated with neurological disorder, the latter abnormality could be reversed in cases of hypoparathyroidism (five out of nine) in contrast with those without hypoparathyroidism ( 0 out of 12). Our patient, Miss V. C., who had hypoparathyroidism and calcification of the basal ganglia, developed choreiform movement only when her serum calcium values were outside the normal ranges.

TABLE

SUMMARY OF CASES OF HYPOPARATHYROIDISM WITH CHOREIFORM MOVEMENT

\begin{tabular}{|c|c|c|c|c|c|c|c|}
\hline Author & $\begin{array}{l}\text { Patient's } \\
\text { age }(y r)\end{array}$ & $\operatorname{Sex}$ & Disease & $\begin{array}{l}\text { Type of } \\
\text { movement }\end{array}$ & $\begin{array}{c}\text { Basal } \\
\text { ganglia } \\
\text { calcification }\end{array}$ & $\begin{array}{l}\text { Serum } \mathrm{Ca} \\
\quad \text { level } \\
(\mathrm{mg} / 100 \mathrm{ml} .)\end{array}$ & Remarks \\
\hline Bronsky et al. (1958) & 16 & $\mathbf{F}$ & $\begin{array}{l}\text { Idiopathic } \\
\text { hypoparathyroid }\end{array}$ & Chorea & Yes & $5 \cdot 8-7 \cdot 4$ & $\begin{array}{l}\text { Choreiform movements } \\
\text { disappeared when serum } \\
\text { calcium was } 9.9 \mathrm{mg} / 100 \mathrm{ml} \text {. No } \\
\text { recurrence of chorea }\end{array}$ \\
\hline Forbes (1956) & & $\mathbf{M}$ & $\begin{array}{l}\text { Idiopathic } \\
\text { hypoparathyroid }\end{array}$ & $\begin{array}{l}\text { Chorea with } \\
\text { head } \\
\text { nodding } \\
\text { and } \\
\text { nystagmus }\end{array}$ & None & $6 \cdot 2-8 \cdot 8$ & $\begin{array}{l}\text { Treatment with vitamin } D \text { and } \\
\text { oral calcium produced } \\
\text { satisfactory response- } \\
\text { movements became less } \\
\text { awkward, head nodding and } \\
\text { nystagmus markedly lessened }\end{array}$ \\
\hline McKinney (1962) & 68 & $\mathbf{F}$ & $\begin{array}{l}\text { Hypoparathyroid } \\
\text { after total } \\
\text { thyroidectomy }\end{array}$ & Chorea & None & $5 \cdot 2$ & $\begin{array}{l}\text { Treated with parenteral and oral } \\
\text { calcium, her chorea improved } \\
\text { considerably }\end{array}$ \\
\hline Simpson (1952) & 9 & $\mathbf{M}$ & $\begin{array}{l}\text { Idiopathic } \\
\text { hypoparathyroidism }\end{array}$ & Chorea & None & $5 \cdot 0-7 \cdot 2$ & $\begin{array}{l}\text { Choreiform state subsided in } \\
\text { about a week. No recurrence } \\
\text { with treatment }\end{array}$ \\
\hline
\end{tabular}


The appearance of involuntary movements in our patients suggests that the cells of the basal ganglia cannot function adequately with low levels of serum calcium. The disorder affects inhibitory influences on thalamocortical pathways concerned in the control of voluntary movement, but the condition is reversible when normal calcium levels are restored.

Epileptic attacks are frequent in about 40 to $50 \%$ of patients with idiopathic hypoparathyroidism (Willison and Whitty, 1957; Dickson, Morita, Cowsert, Graves, and Myer, 1960). The frequency of attacks is less after post-operative hypoparathyroidism, presumably because the hypocalcaemia is less severe. Despite this, epilepsy may manifest itself in patients with hypoparathyroidism without any evidence of overt tetany (Eaton and Haines, 1939; Rose and Vas, 1966). A characteristic of the epileptic seizure in hypocalcaemia is resistance to anticonvulsant therapy (Frame and Carter, 1955; Rose and Vas, 1966). Seizures after hypocalcaemia diminish in frequency initially and finally stop when the level of serum $\mathrm{Ca}^{++}$is raised to normal levels (Eaton and Haines, 1939; Rose and Vas, 1966). Our patient, A.P., showed all these features.

The two patients, taken together, demonstrate the specific and probably causative relation between the serum calcium and symptoms, whatever the form of the symptoms (Eaton and Haines, 1939; Rose and Vas, 1966). Neither the state of agitation, anxiety, and chorea as illustrated in our first patient nor the fits in our second patient could be controlled except by bringing the serum calcium into the normal range.

\section{SUMMARY}

Two patients with idiopathic hypoparathyroidism who developed symptoms of dementia and chorea (as in case 1), and epilepsy (as in case 2) only when their serum calcium was low are described. The symptoms more or less disappeared when their serum calcium was maintained in the normal range.
I am grateful to the late Professor P. Fourman for allowing me to publish the cases and for his constant encourage-D ment in the preparation of the manuscript. I am also grateful to Dr. C. J. Hayter and Dr. P. P. Newman fores their helpful comments and criticisms of the manuscript My thanks to Mrs. S. Rutter for secretarial assistance.

\section{REFERENCES}

Bennet, J. C., Maffly, R. H., and Steinbach, H. L. (1959). The sigz nificance of bilateral basal ganglia calcification. Radiology, 72, 368-378.

Berezin, S. W., and Stein, J. D. (1948). Idiopathic hypoparathyroidism. A case simulating epilepsy and brain tumor. J. Paediat., 33, 346-351.

Bronsky, D., Kushner, D. S., Dubin, A., and Snapper, I. (1958). Idiopathic hypoparathyroidism and pseudohypoparathyroid- $\overline{\mathcal{S}}$ ism: Case reports and review of the literature. Medicine (Baltimore), 37,317-352.

Danowski, T. S., Lasser, E. C., and Wechsler, R. L. (1960). Calcification of basal ganglia in post-thyroidectomy hypopara- $C$ thyroidism. Metabolism, 9, 1064-1065.

Denko, J. D., and Kaelbling, R. (1962). The psychiatric aspects of $\overrightarrow{.}$ hypoparathyroidism. Acta psychiat. scand. Suppl. 161, 38, 二 $1-70$.

Dickson, L. G., Morita, Y., Cowsert, E. J., Graves, J., and Myer, J. S. (1960). Neurological, electroencephalographic, and heredo-familial aspects of pseudohypoparathyroidism and pseudo-pseudohypoparathyroidism. J. Neurol. Neurosurg. Psychiat., 23, 33-39.

Eaton, L. M., and Haines, S. F. (1939). Parathyroid insufficiency with symmetrical cerebral calcification. Report of 3 cases, in one ? of which the patient was treated with dihydrotachyster $\mathrm{E} . \mathrm{G}$ J. Amer. med. Assoc., 113, 749-753.

Forbes, G. B. (1956). Clinical features of idiopathic hypoparathyro就ism in children. Ann. N.Y. Acad. Sci., 64, 432-455.

Frams, B., and Carter, S. (1955). Pseudohypoparathyroidis Clinical picture and relation to convulsive seizures. Neurology I (Minneap.), 5, 297-310.

McKinney, A. S. (1962). Idiopathic hypoparathyroidism present as chorea. Neurology (Minneap.), 12, 485-491.

Mortell, E. J. (1946). Idiopathic hypoparathyroidism with menti deterioration: effect of treatment on intellectual function J. clin. Endocr., 6, 266-274.

Muenter, M. D., and Whisnant, J. P. (1968). Basal ganglia calcification, hypoparathyroidism, and extrapyramidal motor manifestations. Neurology (Minneap.), 18, 1075-1083.

Naef, R. W., and Adle, E. H. (1959). Idiopathic hypoparathyroidism: Report of a case. Ann. intern. Med., 50, 495-505.

Rose, G. A., and Vas, C. J. (1966). Neurological complication and elektroencephalographic changes in hypoparathyroidism. 응 Acta neurol. scand., 42, 537-550.

Simpson, J. A. (1952). The neurological manifestations of idiopathic hypoparathyroidism. Brain, 75, 76-90.

Treusch, J. V. (1957). Idiopathic hypoparathyroidism: Report of an unusual case. Ann. intern. Med., 46, 956-964.

Willison, R. G., and Whitty, C. W. M. (1957). Parathyroid deficiency presenting as epilepsy. Brit. med. J., 1. 802-803. 